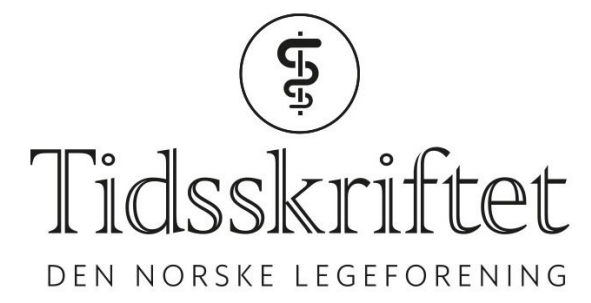

\title{
Rettelse: En tungpustet mann i 50- årene med sirkulatorisk kollaps ved narkose
}

RETTELSE

BENEDIKTE THERESE SMENES

HANS MARTIN FLADE

STEVEN KUDRA

MATTHIAS HEIGERT

ANDERS WINNERKVIST

BJØRNAR GRENNE

Tidsskr Nor Legeforen 2019; 139: 168-72.

I Tidsskriftet nr. 2/2019 på s. 169 i figur 1a skal det nederst til venstre stå: Høyre atrium. Vi beklager feilen, den er rettet på nett.

Publisert: 8. februar 2019. Tidsskr Nor Legeforen. DOI: 10.4045/tidsskr.19.0124

(C) Tidsskrift for Den norske legeforening 2020. Lastet ned fra tidsskriftet.no 